\title{
THE ROLE OF LOCAL GOVERNMENTS IN DEVELOPING NATURAL AND CULTURAL TOURISM IN SUKABUMI DISTRICT
}

\author{
Gumilar Mulyana \\ Institut Pemerintahan Dalam Negeri (IPDN) \\ Email: cepgum07@gmail.com
}

\begin{abstract}
Tourism activities are human activities driven by curiosity and enjoying tourist attractions and tourist attractions without knowing administrative boundaries. Therefore, the concept of integrated regional development can overcome and assist organizational differences between districts into a unity of regional planning and development with tourism activities in Sukabumi Regency. In this research, the method used is a qualitative descriptive approach. Sources of data in this study come from primary data and secondary data. The data collection technique used is field research, such as observation, interviews, and library research. The analysis used by the pen is descriptivequalitative. The research results on tourism's role in developing tourism potential in the Sukabumi Regency are dominant as a facilitator compared to other parts. This role as a facilitator can be seen mainly in the provision of object infrastructure, which is still largely borne by the Tourism Office. Facilities for distributing stimulant fund assistance for people who want to develop a tourism object, promote tourism objects, and facilities provided to third parties such as investors and tourism entrepreneurs to develop their tourism businesses in Sukabumi Regency.
\end{abstract}

Keywords: Government Role, Natural and Cultural Tourism Potential, Sukabumi Regency.

\section{A. INTRODUCTION}

Tourism is a foreign exchange source with the potential and a significant share in increasing a country's economic growth (Kumalasari, 2016). Indonesia's tourism sector is elementary to develop by improving infrastructure, security, and good management to create an attractive tourism sector to local and foreign tourists with a good sense of satisfaction (Mulyono, 2014). In this case, it will create a feeling of wanting to travel again; it will positively impact society and the state. The increase in the tourism sector can also stimulate economic activity, including employment, community income, regional income, and foreign exchange earnings, increasing through efforts to develop various potentials for National Tourism (Hindersah, 2017). Development in the tourism sector is one of the breakthroughs to improve regional and state income. The tourism sector will aligned with other sectors to increase state income, so tourism can be called the tourism industry sector (Mulya, 2020).

Local government policies in tourism development have a significant role in supporting national tourism development (Kadarisman, 2021). The development and growth of tourism need to anticipated to remain on track and carrying capacity (Nugraha, 2020). Development in the area of a tourist attraction will give a substantial contribution if managed professionally; because of the gift to the area concerned, tourism can spur the area's growth around the tourist attraction. Regional autonomy regulations give each region the freedom to manage the resources, such as the 
development of natural resources and human resources. Development planning can identify areas that will serve as tourism development locations (Indah, 2021). This aimed at increasing the role and welfare of the community as widely as possible. The preparation of human resources that have high competence in tourism services is also something that needs to do. It needs to be equipped with technical, operational, and managerial capabilities to provide essential tourism goods (Chia, 2021). Sukabumi Regency is a district located in West Java Province's administrative area because it has a port and waterways. Sukabumi Regency has the potential and resources that can be developed to support the regional autonomy program in the tourism sector so that it has the potential to be developed as a tourist area.

As a district, Sukabumi district has its authority to manage the resources contained in its territory, including the potential resources of its tourism sector (Romao, 2021). Sukabumi Regency has a potential tourism sector to be developed and marketed, starting from nature tourism, cultural tourism, and spiritual tourism. Various likely tourist objects in Sukabumi Regency, this area deserves to be a new and superior tourist destination in Indonesia. All of the above tourism objects are still under the Regency government's control through the Sukabumi Regency Tourism Office. This means that the management and development of tourism objects still rely on incentives from the local government, which in its development with a permit from the local government can be managed by the private sector and the community. Various types of tourism objects in the Sukabumi district can be a significant potential and economic investment in the future, be it for the government, private sector, and the surrounding community. Still, it takes various appropriate protection policies so that sustainability is always created among related stakeholders (Olivera, 2021).

However, it can be said that these tourist objects have not been developed optimally by the local community, managers, and administrators. Facilities and infrastructure that can support tourist objects in the Sukabumi district are still lacking, such as transportation from the city centre to tourist objects, lodging for tourists, and information facilities. This can always be minimal in terms of existing facilities in Sukabumi Regency tourism objects, even though supporting facilities can help develop Sukabumi Regency tourism objects' operating income. The development of these tourist objects, there are several obstacles such as funds for tourism development, this can see from the road conditions that have not repaired, some have not fixed, have not yet built playgrounds around tourist objects and other public facilities (Rani, 2014).

The need for efforts to develop tourist objects in Sukabumi Regency so that they can be of more optimal use, can provide additional income for local people who have income in the tourism sector because there are still many facilities and infrastructure that are still lacking so that it can be said that tourism infrastructure and facilities are inadequate (Yadav, 2021 ). Talking about the development of tourist objects is inseparable from the government's role, especially the tourism office, which is very familiar to our lives (Stokke, 2021). The government's part is essential, especially in protecting tourists and enriching or enhancing their travel experience. The government carries out the implementation of all government regulations and applicable laws. In tourism development, it must be a planned development as a whole so that optimal benefits can 
obtained for the community, both from an economic, social and cultural perspective (Simamora, 2016).

Such planning must integrate tourism development into a country's economic, physical and social development program. Also, the plan must provide adequate infrastructure, management, and security in developing tourism to create a tourism object that has attractiveness and selling power both at home and abroad.

\section{B. METHOD}

In this research, the method used is a qualitative descriptive approach. Researchers chose this method to explore and reveal social phenomena in tourism development in Sukabumi Regency related to the Local Government's Participation, especially in the Culture and Tourism Office of Sukabumi Regency. A research location is a place where the researcher conducts his research. The research location is the Sukabumi Regency Tourism Office. The informants of this research are Head of the Tourism Office; Head of Tourism Development; Tourism NGO/Academic Element; Local communities. There are two sources of data in this study, namely primary data and secondary data. Preliminary data obtained by researchers directly (first hand), namely data in interviews with informants and data obtained from the field (the Department of Culture and Tourism and the Tourism Object). In contrast, secondary data is data obtained by researchers from existing sources, namely literature data that supports primary data such as notebooks or documentation from agencies in the form of attendance, financial reports, and others.

In conducting this research, the data collection techniques that will carried out in the data collection process are: Field Research, observations are carried out directly and systematically by researchers at the Cultural Service Office and the Tourism Office and Tourism Objects in Sukabumi Regency; Interview with the head of the Sukabumi Regency Tourism \& Culture Office and the Tourism Object Manager. Library research in this study is a way of collecting data by reading books and other reading materials relevant to the problem to be studied. Search data online or by using internet facilities.

\section{RESULT AND DISCUSSION}

To develop various regional potentials, including tourism potential, it is necessary to be supported by supporting sectors, namely facilities and infrastructure. The development and improvement of regional facilities and infrastructure to meet the community's needs, such as transportation and irrigation facilities, are constantly faced with limited funding capacity constraints. However, the Sukabumi Regency Government strives to fulfil strategic public facilities which include: (1) Transportation Facilities and Infrastructure; (2) Road and Bridge Construction Program; (3) Rehabilitation and Maintenance of Roads and Bridges to support isolated areas, production centres and strategic roads; and (4) Improvement of roads and bridges to improve the condition of existing roads from dirt roads to open and hot mix to maintain road conditions to be held (Prasodjo, 2017). 
The Road and Bridge Management Program is carried out following the Sukabumi Regency Strategic Plan and is further elaborated in the annual regional development program so that the primary objectives in resolving road and bridge infrastructure problems are: (1) Paying attention to access to isolated areas; (2) Taking into account access to strategic regions; (3) Paying attention to the road to production centres; (5) Provision of inter-regional transportation supporting facilities and infrastructure; and (6) Provision of transportation supporting facilities and infrastructure to potential tourism objects. Development of tourism facilities/infrastructure includes hotels, accommodation, tourist objects, and supporting infrastructure. In 2021, the number of hotels in Sukabumi Regency recorded at 21 units with 542 rooms and 827 beds.

Based on the Regional Regulation of Sukabumi Regency Number 04 of 2008 concerning the Organizational Structure and Work Procedures of the Regional Offices of Sukabumi Regency following Government Regulation Number 41 of 2007 concerning the Organization of Regional Apparatus, Sukabumi Regency Regent Regulation No. 54 of 2008 concerning Job descriptions of Heads of Services, Secretaries, Heads of Subdivisions, Heads of Fields, and Heads of Sections at the Sukabumi Regency Tourism Office, the Sukabumi Regency Tourism Office is an agency that is under and responsible to the Regent of Sukabumi Regency. The Sukabumi Regency Tourism Office led by a Head of Service (Echelon II b). The Head of the Service is assisted by one echelon III A structural official and four echelons IIIB structural officers, and 12 echelon IV structural officials.

The structure of the Sukabumi Regency Tourism Office consists of Head of Office; The Secretariat, consisting of Sub Division of General Affairs; Sub Division of Finance; Sub Division Program; Tourism Development Sector, consisting of; Tourism Object and Attraction Development Section; Tourism Facilities and Services Development Section; The tourism business services industry consists of; Tourism Objects and Attractions Business Section; Business Section for Organizing Attractions, Recreations and General Entertainment; Creative Economy Development Sector, composed of Creative Economy Section Based on Arts and Crafts and Fine Arts and Performances; Creative Economy Section Based on Sound, Music, and Dance.

The Field of Facilities for Development of Tourism Resources and Creative Economy consists of: Section for Promotion and Information of Tourism Resources and Creative Economy; Tourism and Creative Economy Extension Section; Service Technical Implementation Unit (UPTD); Functional Group; Based on the Regional Regulation of Sukabumi Regency Number: 03 of 2006 concerning Amendments to the Regional Regulation of Sukabumi Regency Number: 03 of 2004 concerning the Organizational Structure and Work Procedure of the Regional Offices of Sukabumi Regency, it stipulates that the Tourism Office, Sukabumi Regency has the following main tasks: To carry out the following: Regional authorities include technical policies, planning, implementation, evaluation and control in the arts and culture tourism sector. And based on the Regulation of the Regent of Sukabumi Regency No.54 of 2008 concerning job descriptions of the Head of Service, Secretary, Head of Subdivisions, Heads of Fields and Head of Sections at the Tourism Office, Sukabumi Regency. 
The future development of tourism in Sukabumi Regency refers to several concepts, such as: (1) the idea of sustainable development; (2) Integrated Area Development Concept; (3) Product Development Concept; Marketing and Investment Development Concept; (4) Concept of Development of the Concept of Sustainable Development with the conditions of natural-based tourism potential (mountains, forests, rivers, geological uniqueness, and lakes) and culture that is beginning to be threatened by its sustainability, it is time for tourism development in Sukabumi Regency to be oriented towards regional development that based on community empowerment and orientation. On the principle of sustainability. A regional approach that aims at this needs to accompanied by developing an integration between sectors that expected to function and synergize in regional development (Rusyidi, 2018).

The approach taken refers to the definition of tourism. In the sectoral Agenda 21 book: "Tourism to develop a quality of life sustainably, it places humans as a central theme and fosters prosperity and peace." Following these limitations, 21st-century tourism formulated 2 (two) main missions: increasing competitive advantage and growing tourism contribution to regional development and mutual welfare. With this commitment, tourism in Sukabumi Regency expected to be a driving force for the strategic economic sector and at the same time become a driver for regional development. The nuances of the development and development agendas with a tourism power are more oriented towards product development while still considering the potential of foreign and domestic markets and still paying attention to tourism actors' responsibilities towards preserving and preserving existing tourism resources (Mingkid, 2015).

In the context of tourism development in the Sukabumi Regency, it is essential to integrate and synergize between Sukabumi Regency and other areas, especially with Lake Toba's regencies. One of the reasons from a spatial perspective is that Sukabumi Regency is part of the Sukabumi National Tourism Strategy Area (KSPN) and its surroundings. Based on Ripparnas 2010-2025, these regencies are located in the National Tourism Development Zone (KPPN). Given its geographic proximity, Sukabumi Regency also needs to establish synergy with districts/cities included in the West Java Regional KPPN environment.

In terms of accessibility, the process of entering tourists to the Sukabumi Regency can be developed through the concepts displayed in the motto, for example, "Peaceful and Nice Place to Visit and Enjoy." From the side of integration with other areas in KPPN, KSPN, and the same National Tourism Destination area, it can mutually develop cooperation in developing border areas and transportation routes that connect essential objects in the region the motto Sound of Nature. Tourism development needs to be based on the natural characteristics and socio-cultural dynamics of the community. The features, uniqueness, natural beauty, and Sukabumi Regency culture can be tourists' main attraction (Pengkey, 2016). Therefore, in every planning effort, it is necessary to refer to the natural character and conformity with cultural traditions reflected in the forms, patterns, and spatial structures of the region rooted in aesthetic values and expressions shown in everyday life.

The development of the parts of the region that are relatively advanced need to be consolidated, those that are not yet developed market to be spurred on, and those are starting to 
grow so that they are encouraged to move forward in a directed, planned, and sustainable manner. Therefore, integrated area development considers the level of regional progress and harmony with the development of an area that is still developing to reduce the gap between regions (Nurhadi, 2014).

The concept of developing the main product of tourism in the Sukabumi Regency oriented towards the process and religious history, the potential and attractiveness of beauty, uniqueness, natural charm of the mountains, and the identity and distinctiveness of its history and culture. Orientation to a religious atmosphere, the potential for natural beauty and joy, and the attractiveness of cultural history can be developed into the central theme of tourism products, enabling various levels of society as tourism stakeholders to be involved in tourism development. Likewise, tourism expected to encourage cultural development and community welfare. These cultural dynamics need to be related to the diversity and beauty of natural charm. In developing tourism, it is necessary to pay attention to the carrying capacity and carrying capacity of the environment. Culture and nature are interrelated and influence each other so that the development of tourism products should pay attention to each's characteristics and their interactions as much as possible.

Tourism products developed with themes following the local community's aspirations and the development trend of tourist interest, especially pieces of particular interest that can attract foreign tourists (Windhyastiti, 2016). Tour packages in natural forest areas have their markets, especially for adventure lovers. Tourism themes such as jungle tracking and wildlife conservation can attract foreign tourists to enjoy nature's beauty and invited to participate in helping environmental protection. Mass tourism themes can also be developed because they easily enjoyed by Sukabumi Regency and the people in the surrounding regencies/cities.

The development of tourism products needs to be supported by small and medium industries to empower its economy. This is important because tourism activities are also expected to spur improvement and empowerment of the people's economy, absorption of labour, and strengthen community empowerment. Therefore tourism product development programs should involve small businesses (MSMEs) and cooperatives and develop partnerships with medium-sized enterprises and large tourism investors. The development of tourism products needs to pay attention to product quality standards and essential services such as hygiene, sanitation, hygiene, beauty, and safety. Service standardization with transparent tariffs also needs to be understood by every service provider as well as tourists.

The development of tourism products can carried out in stages according to the community's capacity, local governments' ability, and the tenacity of business actors in seeing and managing tourism potential into valuable products. This means that the development of tourism products is carried out not in a mass manner and with drastic changes but carefully and gradually. Priority for development carried out with the support of planned concrete programs and activities. Thus all parties will learn from the process of success or failure of developing a tourism product. One of the principles of tourism product development is the learning process from shared experiences. It hoped that tourism development business activities would become a locomotive in 
dynamizing the regional economy. The tourism development concept in Sukabumi Regencydirected at religious tourism, culture, and the highlands' natural beauty, where tourists can enjoy inner tranquillity, cultural uniqueness, and natural beauty. They also expected to participate directly in cultural and environmental conservation activities and gain a deeper understanding of the cultural ecosystem's ins and outs. And natural mountains. The interaction of tourists with the community is expected to build awareness of mutual respect for each's values and cultural procedures, and both of them strive to remain sustainable.

Tourism marketing development needs to pay attention to market segments and tourist characteristics. The existing trends need to be studied and investigated with promotional efforts more deeply so that tourists who have come want to repeat the experience. The history of missions in the past seems to processed into promotions for tourists from Europe. Meanwhile, product diversification and marketing should also be carried out, especially for tourists from neighbouring countries such as Malaysia, Singapore, Brunei, and other Asian countries. Sukabumi Regency tourism marketing needs to planned systematically and thematically. Besides, it is necessary to carry out integrated marketing and marketing and promotion efforts not individually to reach a broader and more precise market.

Several obstacles cause foreign and domestic investors to be reluctant to invest in Sukabumi District immediately: Limited infrastructure will affect the smoothness of investing because it will increase investment costs higher; a long bureaucracy will cause high prices, which called the high-cost economy; Due to limited funding sources, it is often difficult for the banking sector to launch funds for tourism businesses which usually carried out by small economic actors who considered to have high credit risk.

Some parts of the tourist area are located in hard to reach topography. Several potential objects, such as waterfall tourism objects and ecotourism objects, are generally located in steep areas. Apart from that, some of these objects found in protected areas require special procedures for their utilization. Several other things located in disaster-prone areas, such as ecotourism, cultural tourism, agro-tourism, and tourism areas in Muara District, prone to landslides. In general, Sukabumi Regency indeed crossed by geological faults, one of the sources of earthquakes. By looking at the existing problems, the Sukabumi Regency Government, together with the community, must try to minimize the physical obstacles that occur. The formation of tourism institutions, especially in the regions, is essential for reasons that can be briefly presented: integrating all tourism elements into a holistic unit. The tourism system will run better if driven by an institutional mechanism that includes all the main tourism actors.

Partnerships arise from several groups agreeing to work together in an institutional forum to achieve common goals; If the community builds a tourism object for residents, then a regional tourism identity can be made with an institutional platform. The Sundanese tribe is a tribe that has a powerful religious spirit, cultural characteristics, and local wisdom so that this potential can be appointed as the primary identity in the main in the formation and operation of institutions; help cooperation; Public and private institutions (tourism stakeholders) can work together to achieve common goals if they are all involved in an organizational forum. 
Therefore, institutional planning must start from exploring strategic issues that can explain what problems are developing in each element or element of the Sukabumi Regency tourism system. On that basis, activities carried out to identify each element's potential and existence and continued with a description of the strategic functions that needed to carried out. For Sukabumi Regency, which classified as a developing district, planning and institutional strengthening in the medium term need to prioritized for strengthening the role of local institutions, including traditional or customary institutions. It often found that the managers of existing tourist destination objects (ODTW) are not aware of the importance of mountain forests' environmental management. Large-scale exploitation of mountain forest resources and exploitation of mining materials in the economic development framework causes quite severe ecological damage. The negative impact of the excessive and undirected exploitation of natural resources in the mountains can be felt directly by the village community.

The destruction of forest areas due to exploitation and illegal logging has led to landslides in several places. This is a process that occurs naturally, but the incident is exacerbated by humans who have cut down forest wood, both to exploit the economic value of timber and land conversion into plantations, settlements, and ponds illegal building sites. Damage to mountain forests has other negative impacts that are felt directly by the community itself, including the reduction of forest products, the difficulty of obtaining large diameter wood, the difficulty of securing honey, incense, rattan, and water sources. Apart from the destruction of mountain forests, pollution has also contributed to the damage to the mountainous and aquatic environment, both liquid waste and solid waste originating from industry and households.

If this happens to tourism objects in Sukabumi Regency, environmental damage will continue to occur. As a result, tourists visiting ODTW, which has damaged its environment, will decrease. Therefore, before the ecological damage is too severe, it needs to be handled immediately. When viewed from the principle of Sapta Pesona Wisata, there are several points related to the environment. Cleanliness, beauty, and comfort are items associated with the direction of preserving the environment. In general, an important issue that must be the basis for any development design in an area or tourism object is to keep it from exceeding its carrying capacity.

The government has launched an attraction program which defined as (natural resources, human resources, culture, etc.) that need to developed to become tourist attractions. One of them is the 2019 Ciletuh Geopark Festival (CGF) in the Batu Karut Samudera Beach Hotel, Palabuhanratu Tourism, Pangandaran Regency. The activity, which the Sukabumi Regency Tourism Office held together with the Ministry of Tourism of the Republic of Indonesia, was themed "Sound of Nature." The event featured dance, traditional and contemporary music attractions, and the Surfing sports Peselanar attraction. Other attractions provided by the Tourism Office, such as Seren Taun, lojor dogdog, rengkog, which have been packaged by the local Kasepuhan community. However, the Dinas usually facilitate it for a fee. It is one of the cultural attractions in Kasepuhan. The ceremonial Kasepuhan title's authenticity has maintained for 651 years, with a traditional culture still attached. Then the fishermen's thanksgiving or fishermen's day, the agency facilitates and supports funds for these attractions. Then there are also activities 
organized by the Dinas, such as Jaipongan and cultural carnivals. The interest that provided for the first time is from nature itself.

"Nature from God" has become the motto because people think God has provided the beauty and completeness of tourism in Sukabumi Regency. Then the Sukabumi government maintains and develops this sector. The 4 elements of culture have also included the Sukabumi Regency government's efforts, such as guidance, development, protection, and utilization. Then the government also provides tourism facilities that support tourism development. Then the essential elements that include tourism development are the development of tourist amenities and accommodation. According to Carter and Fabricius, the necessary facilities are roads, transportation, housing, information centres, and shopping centres. The amenities that the tourism office has provided include lodging in Cinumpang, then camping ground, places of worship such as prayer rooms and toilets.

The accommodation provided at tourist attractions, including in the Halimun and Cinumpang huts, has provided lodging. Still, if there are tourists who want to stay at hotels in Salabintana, it returns to the choice and comfort of the tourists themselves. Regarding the tourism facilities provided by the Sukabumi Regency government, such as souvenir places, game equipment, and restaurants so that tourists can eat comfortably and have easy access to reach. There are also photo spot facilities and information papa related to particular tourist objects that can be accessed widely through social media. Then in the arts and culture aspect, the government provides facilities for the development of GURILAPSS during big days. The tourism office's future efforts for tourism amenities and accommodation, namely by building gazebos, building more toilets, and building prayer rooms, are some of the agency's efforts to improve tourism amenities and capacity. GIC (Geopark Information Center) is currently an information centre for tourists visiting Sukabumi and a centre for Tour Guides for tourists who need these services.

The Sukabumi Regency Tourism Office's tourism potential development activities realized in two parts: the tourism potential development section itself and the tourism marketing and promotion section. Each of these sections has its role in developing tourism potential in Sukabumi Regency. The tourism development section has a role and obligation to accommodate facilities and infrastructure in all tourism objects and tourism businesses in Sukabumi Regency, such as providing access to tourism objects, providing toilets, providing counters, and entrance fees tourists objects, and so on. In contrast, the marketing and tourism promotion sections play a significant role in promoting tourism objects in Sukabumi Regency to tourists through various prearranged programs. Apart from being used as a source of regional income, tourism development can also use to preserve local culture and wisdom. By looking at the variety of tourism potentials in the Sukabumi Regency, the Regional Government as one of the stakeholders in tourism development should be able to optimize this potential for the welfare of the people of Sukabumi Regency.

Investors and tourism entrepreneurs as parties directly related to tourists should also contribute more to tourism development so that local governments as tourism stakeholders are not overwhelmed, especially in financing tourism development; furthermore; local governments must 
synergize with other parties. , so that the problem of limited resources can overcome. In Good Governance's pillars, the dynamist, for an ideal development to take place, the government, private sector, and society must work together well. As one of the tourism development stakeholders in the Sukabumi Regency, the local government has a role in synergizing the three parties. In other things, a mutualism symbiosis created for the development of tourism.

Upaya untuk mensinergiskan antar stakeholder ini peneliti nilai masih dalam taraf normal, namun mengingat kondisi pariwisata di Kabupaten Sukabumi yang membutuhkan suatu inovasi lebih, pemerintah daerah seharusnya perlu meningkatkan perannya ini secara lebih intens lagi. Berdasarkan hasil observasi peneliti, masih banyak obyek wisata di Kabupaten Sukabumi yang pengembangannya masih didominasi oleh peran dari pemerintah, sedangkan peran dari pihak swasta dan masyarakat masih minim.

Local government efforts to synergize tourism development stakeholders are not easy, given the lack of participation from the private sector and the community in developing tourism in Sukabumi Regency. Seeing this, the researchers considered it necessary to carry out a routine and massive consolidation between industries. The local government acts as an intermediary to hope that a synergistic cross-sectoral innovation can emerge.

\section{CONCLUSION}

The tourism development of Sukabumi Regency refers to several concepts, such as (1) the idea of sustainable development, (2) tourism development by still considering the potential of foreign and domestic markets, and (3) tourism development by taking into account the responsibilities of tourism actors towards the preservation and preservation of resources. Existing tourism.

The role of tourism in the development of tourism potential in the Sukabumi Regency is dominant as a facilitator compared to other parts, namely as a motivator and dynamist. This role as a facilitator can be seen mainly in the provision of facilities and infrastructure for objects which are still primarily borne by the agency, facilities for distributing stimulant funds for people who want to develop a tourism object, efforts to promote tourism objects, and facilities provided to third parties such as investors and entrepreneurs. Tours to grow their tourism business in Sukabumi Regency. The following are the three roles of the Tourism Culture Office in the Development of Tourism Potential in Sukabumi Regency: As a Facilitator, To carry out its position, the Tourism Office makes it happen by providing facilities and infrastructure in tourism objects, providing facilities to investors and tourism entrepreneurs in the form of policies and regulations. This can protect and benefit tourism investors and entrepreneurs, market tourism objects, facilitate tourismconscious community groups to get stimulant funds, etc. This is important to do so that investors and tourism entrepreneurs in Sukabumi Regency can develop their business optimally so that tourism objects can design well.

As a Motivator, the Tourism Office, as one of the tourism stakeholders in Sukabumi Regency, motivates the community, investors, and tourism entrepreneurs. The importance of community awareness in the Sukabumi Regency about the significance of tourism demands the 
Tourism Office's role to continue to provide motivation, be it in socialization, training, or stimulant funds. Cause also needs to continue to be given to investors and tourism entrepreneurs in Sukabumi Regency so that these tourism investors and entrepreneurs are interested in developing their tourism business in Sukabumi Regency, and indirectly they can also ease the budget burden from the Tourism Office in the context of developing tourism potential in Sukabumi Regency.

\section{REFERENCES}

Chia, S. K. S., Lo, M. C., Razak, Z. B., Wang, Y. C., \& Mohamad, A. A. (2021). Impact of Destination Image on Tourist Satisfaction: The Moderating Effect of Information Technology (IT). GeoJournal of Tourism and Geosites, 34(1), 88-93.

Hindersah, H., Asyiawati, Y., Akliyah, L. S., \& Ramadhan, T. A. (2017). Tantangan Pembangunan Pariwisata Inklusif Geopark Ciletuh, Desa Ciwaru Kabupaten Sukabumi-Provinsi Jawa Barat. In Prosiding-Seminar-Nasional-Perencanaan-Pembangunan-Inklusif-Desa-Kota, 6(3), 125-134).

Indah, A. O., \& Valeriani, D. (2021). Capaian Kinerja Berdasarkan Realisasi Keuangan dan Realisasi Fisik Pada Dinas Kebudayaan dan Pariwisata Provinsi Kepulauan Bangka Belitung. Jurnal Manajemen Kompeten, 3(2), 1-13.

Kadarisman, A. (2021). Government public relations dalam pengembangan pariwisata masa pandemi COVID-19 di Geopark Ciletuh. PRofesi Humas, 5(2), 270-290.

Kumalasari, D., \& Riharjo, I. B. (2016). Transparansi dan akuntabilitas pemerintah desa dalam pengelolaan alokasi dana desa. Jurnal Ilmu dan Riset Akuntansi (JIRA), 5(11).

Mingkid, E. (2015). Penggunaan media komunikasi promosi pariwisata oleh pemerintah Kota Manado. Sosiohumaniora, 17(3), 188-192.

Mulya, I. S., Hernawan, D., \& Fitriah, M. (2020). Pengembangan Pariwisata Kabupaten Sukabumi Melalui Tagline Gurilapss Pesona Sukabumi. Jurnal Komunikatio, 6(2), 56-71.

Mulyono, S. P. (2014). Sinergitas Penyelenggaraan pemerintahan desa pasca pemberlakuan UU No. 6 Tahun 2014 tentang desa. Masalah-Masalah Hukum, 43(3), 438-444.

Nugraha, A. M. (2020). Corporate Social Responsibility (CSR) PT. Aqua Golden Mississppi Mekarsari Pada Program Pemberdayaan Ekonomi Pelaku Usaha Mikro Kecil Menengah (UMKM) di Kecamatan Cicurug, Kabupaten Sukabumi (Bachelor's thesis, Fakultas Ilmu Dakwah dan Ilmu Komunikasi Universitas Islam Negeri Syarif Hidayatullah Jakarta).

Nurhadi, F. D. C. (2014). Strategi Pengembangan Pariwisata Oleh Pemerintah Daerah Terhadap Pendapatan Asli Daerah (PAD)(Studi Pada Dinas Pemuda, Olahraga, Kebudayaan Dan Pariwisata Kabupaten Mojokerto). Jurnal Administrasi Publik, 2(2), 325-331.

Olivera, V. A. J., \& Carrillo, I. M. (2021). Organizational Culture: A Key Element for the Development of Mexican Micro and Small Tourist Companies. In Innovation and Entrepreneurial Opportunities in Community Tourism, 6(4), 227-242.

Pangkey, I., \& Pinatik, S. (2016). Analisis efektivitas dan efisiensi anggaran belanja pada dinas kebudayaan dan pariwisata provinsi Sulawesi Utara. Jurnal EMBA: Jurnal Riset Ekonomi, Manajemen, Bisnis dan Akuntansi, 3(4).

Prasodjo, T. (2017). Pengembangan Pariwisata Budaya dalam Perspektif Pelayanan Publik. Jurnal Office, 3(1), 7-12.

Primadany, S. R. (2013). Analisis strategi pengembangan pariwisata daerah (studi pada dinas kebudayaan dan pariwisata daerah kabupaten nganjuk). Jurnal Administrasi Publik, 1(4), 135-143. 


\section{ARTIKEL}

Rani, D. P. M. (2014). Pengembangan potensi pariwisata kabupaten sumenep, madura, jawa timur (studi kasus: pantai lombang). Jurnal Politik Muda, 3(3), 412-421.

Romao, J., Okada, M., Machino, K., \& Nijkamp, P. (2021). Destination management and sustainable development through the standard lens of the Commons. REGION, 8(1), 7595.

Rusyidi, B., \& Fedryansah, M. (2018). Pengembangan Pariwisata Berbasis Masyarakat. Focus: Jurnal Pekerjaan Sosial, 1(3), 155-165.

Simamora, R. K., \& Sinaga, R. S. (2016). Peran pemerintah daerah dalam pengembangan pariwisata alam dan budaya di Kabupaten Tapanuli Utara. JPPUMA: Jurnal Ilmu Pemerintahan dan Sosial Politik UMA (Journal of Governance and Political Social UMA), 4(1), 79-96.

Stokke, K. B., Clemetsen, M., Aas, Ø., Haugen, T. O., Stensland, S., \& Haraldseid, T. (2021). Frameworks to understand natural and cultural resources in nature-based tourism. In Nordic Perspectives on Nature-based Tourism. Edward Elgar Publishing.

Windhyastiti, I., \& Widiawati, D. (2016). Pentingnya Aspek Goverment Power Dalam Pengembangan Industri Pariwisata Daerah. Jurnal Manajemen dan Kewirausahaan, 4(1), 69-83.

Yadav, J. K., Verma, D. C., Jangirala, S., \& Srivastava, S. K. (2021). An IAD Type Framework for Blockchain-enabled Smart Tourism Ecosystem. The Journal of High Technology Management Research, 6(4), 35-40. 